Article

\title{
Paradoxical Patterns of Sinusoidal Obstruction Syndrome-Like Liver Injury in Aged Female CD-1 Mice Triggered by Cannabidiol-Rich Cannabis Extract and Acetaminophen Co-Administration
}

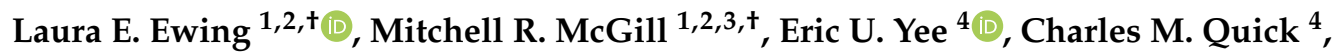 \\ Charles M. Skinner 1,3, Stefanie Kennon-McGill ${ }^{1}$, Melissa Clemens ${ }^{2}$, Joel H. Vazquez ${ }^{2}$, \\ Sandra S. McCullough ${ }^{2,5}$, D. Keith Williams ${ }^{6}$, Kristy R. Kutanzi ${ }^{1}$, Larry A. Walker ${ }^{7,8}$, \\ Mahmoud A. ElSohly ${ }^{7,8,9}$, Laura P. James ${ }^{2,5}$, Bill J. Gurley ${ }^{3,10}$ and Igor Koturbash 1,3,*(D) \\ 1 Department of Environmental and Occupational Health, University of Arkansas for Medical Sciences, \\ Little Rock, AR 72205, USA; LEEwing@uams.edu (L.E.E.); MRMcgill@uams.edu (M.R.M.); \\ CMSkinner@uams.edu (C.M.S.); SKennonmcgill@uams.edu (S.K.-M.); kristy.kutanzi@gmail.com (K.R.K.) \\ 2 Department of Pharmacology and Toxicology, University of Arkansas for Medical Sciences, \\ Little Rock, AR 72205, USA; MMClemens@uams.edu (M.C.); JVazquez@uams.edu (J.H.V.); \\ McCulloughSandraS@uams.edu (S.S.M.); jameslaurap@uams.edu (L.P.J.) \\ 3 Center for Dietary Supplements Research, University of Arkansas for Medical Sciences, \\ Little Rock, AR 72205, USA; GurleyBillyJ@uams.edu \\ 4 Department of Pathology, University of Arkansas for Medical Sciences, Little Rock, AR 72205, USA; \\ EYee@uams.edu (E.U.Y.); QuickCharlesM@uams.edu (C.M.Q.) \\ 5 Department of Pediatrics, University of Arkansas for Medical Sciences, Little Rock, AR 72205, USA \\ 6 Department of Biostatistics, University of Arkansas for Medical Sciences, Little Rock, AR 72205, USA; \\ WilliamsDavidK@uams.edu \\ 7 National Center for Natural Products Research, University of Mississippi, University, MS 38677, USA; \\ lwalker@olemiss.edu (L.A.W.); melsohly@olemiss.edu (M.A.E.) \\ 8 ElSohly Laboratories, Inc. (ELI), Oxford, MS 38677, USA \\ 9 Department of Pharmaceutics and Drug Delivery, School of Pharmacy, University of Mississippi, University, \\ MS 38677, USA \\ 10 Department of Pharmaceutical Sciences, University of Arkansas for Medical Sciences, \\ Little Rock, AR 72205, USA \\ * Correspondence: ikoturbash@uams.edu; Tel.: +1-501-526-6638 \\ + These authors contributed equally to this work.
}

Received: 21 May 2019; Accepted: 13 June 2019; Published: 17 June 2019

\begin{abstract}
The goal of this study was to investigate the potential for a cannabidiol-rich cannabis extract (CRCE) to interact with the most common over-the-counter drug and the major known cause of drug-induced liver injury-acetaminophen (APAP)-in aged female CD-1 mice. Gavaging mice with $116 \mathrm{mg} / \mathrm{kg}$ of cannabidiol (CBD) [mouse equivalent dose (MED) of $10 \mathrm{mg} / \mathrm{kg}$ of CBD] in CRCE delivered with sesame oil for three consecutive days followed by intraperitoneally (i.p.) acetaminophen (APAP) administration $(400 \mathrm{mg} / \mathrm{kg}$ ) on day 4 resulted in overt toxicity with $37.5 \%$ mortality. No mortality was observed in mice treated with $290 \mathrm{mg} / \mathrm{kg}$ of CBD+APAP (MED of $25 \mathrm{mg} / \mathrm{kg}$ of CBD) or APAP alone. Following CRCE/APAP co-administration, microscopic examination revealed a sinusoidal obstruction syndrome-like liver injury-the severity of which correlated with the degree of alterations in physiological and clinical biochemistry end points. Mechanistically, glutathione depletion and oxidative stress were observed between the APAP-only and co-administration groups, but co-administration resulted in much greater activation of c-Jun N-terminal kinase (JNK). Strikingly, these effects were not observed in mice gavaged with $290 \mathrm{mg} / \mathrm{kg}$ CBD in CRCE followed by APAP administration. These findings highlight the potential for CBD/drug interactions, and reveal an interesting paradoxical effect of CBD/APAP-induced hepatotoxicity.
\end{abstract}


Keywords: acetaminophen; cannabidiol; liver injury; natural products; phytochemical; sinusoidal obstruction syndrome

\section{Introduction}

Cannabidiol (CBD) is one of the major phytocannabinoids in Cannabis sativa that has seen a dramatic increase in popularity over recent years due to expanded availability and aggressive marketing. Though CBD is regarded as lacking psychotropic activity, it does display a number of neuropharmacological effects, including anti-seizure activity. CBD, as the prescription drug EPIDIOLEX®, recently received the US Food and Drug Administration (FDA) approval, with indications for treatment of certain severe forms of epilepsy [1,2]. Although that makes it a regulated drug in some forms, it is still widely marketed in an array of over-the-counter products in variable forms, and touted as a treatment for various medical conditions ranging from depression to arthritis and cancer [3,4].

Emerging evidence, however, indicates that CBD poses a significant risk for hepatotoxicity. A number of animal studies have reported increased liver weights, elevation of liver enzymes and bilirubin in circulation as well as molecular signatures of hepatotoxicity after administration of CBD or cannabidiol-rich cannabis extract (CRCE) [5-7]. In clinical trials, elevated liver enzymes were observed in $5-20 \%$ of patients treated with CBD, and several patients were withdrawn due to the threat of liver failure $[1,2,8]$.

Evolving evidence suggests that $\mathrm{CBD}$ has the potential to induce drug interactions, involving the modulation of various cytochrome P450 (CYP) and UDP-glucuronosyltransferase (UGT) enzymes responsible for xenobiotic metabolism [7,9-11]. CBD was shown to modulate CYP2E1 and CYP1A2, two of the more common P450 enzymes involved in drug metabolism and drug-induced hepatotoxicity (e.g., acetaminophen (APAP) and ethanol). Such an interaction potential is especially concerning among the elderly, as CYP activity and drug clearance are known to be impaired with age [12,13]. Furthermore, rates of drugs use increase with age, with the highest overall prevalence observed in older women, of whom $94 \%$ take at least 1 medication, and 57\% take 5 or more medications [14]. Lastly, recent research indicates that herbal dietary supplements pose a greater risk for hepatotoxicity among women (with similar patterns observed in female mice) [15-17]. Therefore, the goal of this study was to investigate the CBD/APAP interaction potential in aged female CD-1 mice.

\section{Results and Discussion}

\subsection{Overt Toxicity Associated with CRCE/APAP Administration}

Female, 9 month old, CD1 mice were gavaged over three consecutive days with vehicle, 116, or $290 \mathrm{mg} / \mathrm{kg} \mathrm{CBD}$. On the fourth day, mice were injected with either PBS or $400 \mathrm{mg} / \mathrm{kg}$ APAP. Three of the mice treated with $116 \mathrm{mg} / \mathrm{kg}$ CBD + APAP $(n=8)$ succumbed within $5 \mathrm{~h}$ of APAP dosing. No mortality was observed in the $290 \mathrm{mg} / \mathrm{kg}$ CBD+APAP or Veh+APAP mice. Mice in the CBD+APAP groups developed a sub-lethargic condition which was characterized by a substantial decrease in activity, nuzzling into bedding material, impaired response to external stimuli, and a decrease in body temperature. Veh+APAP mice developed hypothermia only.

Fluctuations in body weights were observed in mice among all experimental groups; however, in $116 \mathrm{mg} / \mathrm{kg}$ CBD+APAP mice there were statistically significant decreases in body weights $(-4 \%$, $p<0.05$ ) (Supplementary Figure S1A). Furthermore, significant increases in liver-to- body weight (LBW) ratios were observed in $116 \mathrm{mg} / \mathrm{kg}$ CBD + APAP $(p<0.01)$ (Supplementary Figure S1B). No significant differences were observed in heart-or kidney-to-body weight ratios (Supplementary Figure S1C,D). 


\subsection{CRCE/APAP Cause Acute Liver Injury}

Histopathological evaluation of liver samples revealed abnormalities in the $116 \mathrm{mg} / \mathrm{kg}$ CBD+APAP mice manifested as a sinusoidal obstruction syndrome, or SOS, pattern of injury (Figure 1). Specifically, diffuse, centrivenular-dominant regions of sinusoidal dilation accompanied by marked vascular congestion, hepatic plate atrophy, and centrivenular necrosis were observed in the livers of six mice in this group (Table 1). However, foci of sinusoidal destruction were observed in the livers of only two out of eight mice in $290 \mathrm{mg} / \mathrm{kg}$ CBD + APAP and one out of seven mice in the Veh+APAP group.
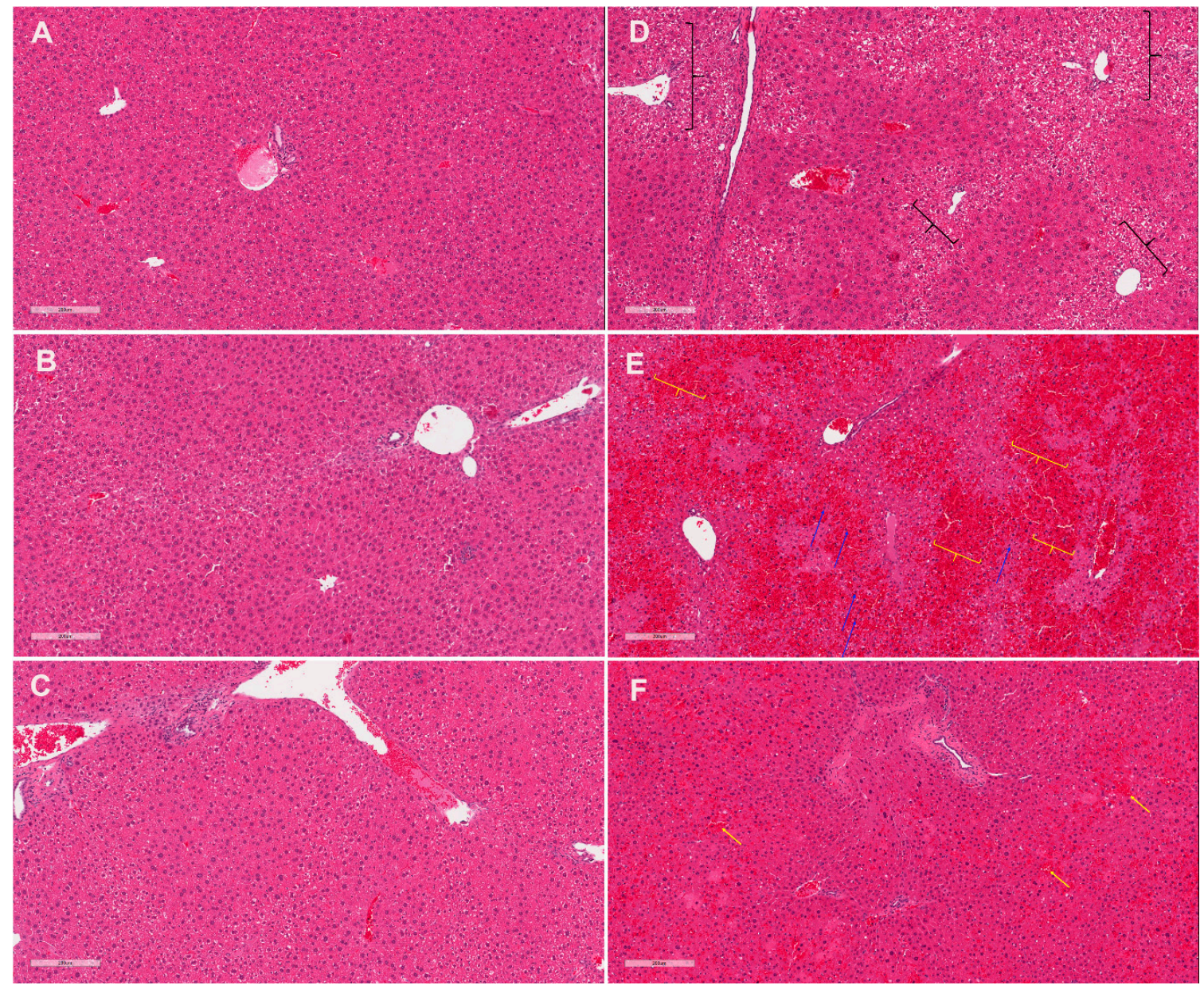

Figure 1. Co-administration of cannabidiol-rich cannabis extract (CRCE) and APAP results in sinusoid obstructive syndrome-like histomorphological alterations in the livers of aged female CD-1 mice. H\&E stained liver sections from (A) vehicle-gavaged mice (sesame oil), (B) $116 \mathrm{mg} / \mathrm{kg}$ CBD, (C) $290 \mathrm{mg} / \mathrm{kg} \mathrm{CBD,} \mathrm{(D)} \mathrm{APAP} \mathrm{(400} \mathrm{mg/kg),} \mathrm{(E)} 116 \mathrm{mg} / \mathrm{kg}$ CBD+APAP, (F) $290 \mathrm{mg} / \mathrm{kg}$ CBD+APAP. Black brackets indicate areas of clear cell changes (D), yellow brackets (E) and arrows (F) indicate areas of sinusoidal dilation with vascular congestion, and blue arrows (E) indicate areas of hepatic plate atrophy. CRCE—cannabidiol-rich cannabis extract; APAP_acetaminophen. Magnification: X10.

Table 1. Histopathological evaluation of mouse livers using a modified Rubbia-Brandt sinusoid obstructive syndrome (SOS)-I scoring system.

\begin{tabular}{ccccccc}
\hline & $\begin{array}{c}\text { Vehicle } \\
(\boldsymbol{n}=7)\end{array}$ & $\begin{array}{c}\mathrm{CBD}, \mathbf{1 1 6} \\
\mathbf{m g} / \mathbf{k g}(\boldsymbol{n}=\mathbf{7})\end{array}$ & $\begin{array}{c}\mathrm{CBD}, \mathbf{2 9 0} \\
\mathbf{m g} / \mathbf{k g}(\boldsymbol{n}=\mathbf{8})\end{array}$ & $\begin{array}{c}\text { APAP }(400 \\
\mathbf{m g} / \mathbf{k g})(\boldsymbol{n}=7)\end{array}$ & $\begin{array}{c}\text { CBD, 116 mg/kg CBD, 290mg/kg } \\
+ \text { APAP }(\boldsymbol{n}=\mathbf{8})\end{array}$ & $\begin{array}{c}\text { CB APAP }(\boldsymbol{n}=\mathbf{8}) \\
+\end{array}$ \\
\hline Sinusoidal dilation & $0.0 \pm 0.0$ & $0.0 \pm 0.0$ & $0.1 \pm 0.1$ & $0.9 \pm 0.4$ & $2.0 \pm 0.5^{*}$ & $0.8 \pm 0.5$ \\
\hline Venous obstruction & $0.0 \pm 0.0$ & $0.0 \pm 0.0$ & $0.0 \pm 0.0$ & $0.0 \pm 0.0$ & $0.0 \pm 0.0$ & $0.0 \pm 0.0$ \\
\hline Atrophy & $0.0 \pm 0.0$ & $0.0 \pm 0.0$ & $0.0 \pm 0.0$ & $0.3 \pm 0.2$ & $0.6 \pm 0.2$ & $0.3 \pm 0.2$ \\
\hline Apoptosis & $0.0 \pm 0.0$ & $0.0 \pm 0.0$ & $0.0 \pm 0.0$ & $0.0 \pm 0.0$ & $0.1 \pm 0.1$ & $0.1 \pm 0.1$ \\
\hline
\end{tabular}


Table 1. Cont.

\begin{tabular}{|c|c|c|c|c|c|c|}
\hline & $\begin{array}{l}\text { Vehicle } \\
(n=7)\end{array}$ & $\begin{array}{c}\mathrm{CBD}, 116 \\
\mathrm{mg} / \mathrm{kg}(n=7)\end{array}$ & $\begin{array}{c}\mathrm{CBD}, 290 \\
\mathrm{mg} / \mathrm{kg}(n=8)\end{array}$ & $\begin{array}{c}\text { APAP }(400 \\
\mathrm{mg} / \mathrm{kg})(n=7)\end{array}$ & $\begin{array}{l}\text { CBD, } 116 \mathrm{mg} / \mathrm{kg} \\
+\operatorname{APAP}(n=8)\end{array}$ & $\begin{array}{l}\text { CBD, } 290 \mathrm{mg} / \mathrm{kg} \\
+ \text { APAP }(n=8)\end{array}$ \\
\hline Necrosis & $0.0 \pm 0.0$ & $0.0 \pm 0.0$ & $0.0 \pm 0.0$ & $0.7 \pm 0.6$ & $2.0 \pm 0.6^{*}$ & $0.8 \pm 0.4$ \\
\hline Microvesicular steatosis & $0.0 \pm 0.0$ & $0.0 \pm 0.0$ & $0.0 \pm 0.0$ & $0.0 \pm 0.0$ & $0.0 \pm 0.0$ & $0.0 \pm 0.0$ \\
\hline Small droplet steatosis & $1.0 \pm 0.3$ & $0.7 \pm 0.4$ & $0.6 \pm 0.3$ & $0.3 \pm 0.3$ & $1.0 \pm 0.3$ & $1.1 \pm 0.3$ \\
\hline Large droplet steatosis & $0.0 \pm 0.0$ & $0.0 \pm 0.0$ & $0.1 \pm 0.1$ & $0.1 \pm 0.1$ & $0.0 \pm 0.0$ & $0.0 \pm 0.0$ \\
\hline Clear cell changes & $0.0 \pm 0.0$ & $0.3 \pm 0.3$ & $0.8 \pm 0.3$ & $1.4 \pm 0.4$ & $0.6 \pm 0.4$ & $1.3 \pm 0.5$ \\
\hline Portal inflammation & $0.2 \pm 0.1$ & $0.0 \pm 0.0$ & $0.1 \pm 0.1$ & $0.0 \pm 0.0$ & $0.5 \pm 0.4$ & $0.0 \pm 0.0$ \\
\hline Lobular inflammation & $0.9 \pm 0.2$ & $1.2 \pm 0.3$ & $0.8 \pm 0.2$ & $0.6 \pm 0.2$ & $1.4 \pm 0.6$ & $0.8 \pm 0.2$ \\
\hline Interface activity & $0.0 \pm 0.0$ & $0.0 \pm 0.0$ & $0.0 \pm 0.0$ & $0.0 \pm 0.0$ & $0.4 \pm 0.4$ & $0.0 \pm 0.0$ \\
\hline
\end{tabular}

Scores between vehicle and APAP groups at each dose of CBD were analyzed with a Mann-Whitney test and a Bonferroni correction for multiple comparisons. Significance was therefore determined at $\alpha \leq 0.0167$. Data presented as average scores for each parameter \pm SEM with an *indicating a significant difference between vehicle and APAP groups at the corresponding dose of CBD. Liver samples of all experimental animals $(n=45)$ were evaluated. Details on scoring parameters are provided in the Supplementary Materials and Methods Section.

No significant differences were observed in the serum levels of total bilirubin and AST in experimental mice. This was likely due, in part, to the fact that serum samples were not available from deceased animals in the $116 \mathrm{mg} / \mathrm{kg}$ CBD + APAP group, nor from several moribund mice whose condition precluded adequate blood volume withdrawal. However, elevated serum levels of ALT were observed in $116 \mathrm{mg} / \mathrm{kg}$ CBD+APAP mice, compared to the control mice (Figure 2), and the extent of alterations in physiological (body weight, LBW) and clinical biochemistry endpoints significantly correlated with the degree of liver injury (Table 2).
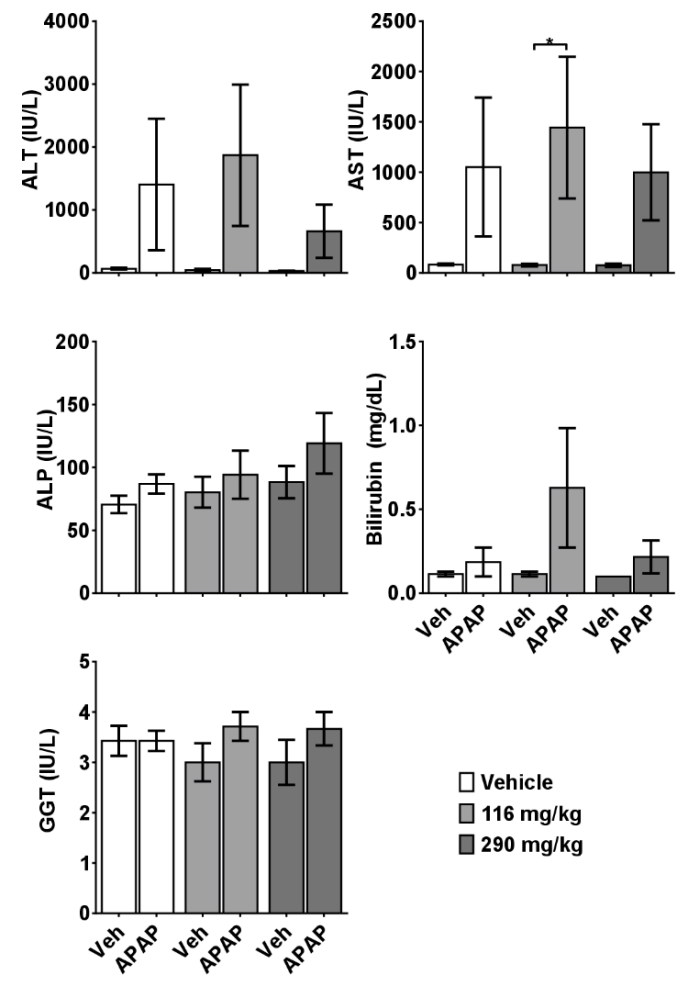

$\square$ Vehicle

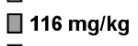

$\square 290 \mathrm{mg} / \mathrm{kg}$

Figure 2. Effects of CRCE/APAP co-administration on commonly assessed clinical chemistry parameters for liver injury. Blood was collected at the time of sacrifice, and the serum was subsequently separated and removed for analysis. Veh $(n=7) ; \operatorname{Veh}+\operatorname{APAP}(n=7) ; 116 \mathrm{mg} / \mathrm{kg} \mathrm{CBD}(n=7) ; 116 \mathrm{mg} / \mathrm{kg}$ $\mathrm{CBD}+\mathrm{APAP}(n=5) ; 290 \mathrm{mg} / \mathrm{kg} \mathrm{CBD}(n=7) ; 290 \mathrm{mg} / \mathrm{kg} \mathrm{CBD}+\mathrm{APAP}(n=6)$. Data are presented as mean \pm SEM $\left({ }^{*} p<0.05\right)$. ALT: alanine aminotransferase; AST: aspartate aminotransferase; ALP: alkaline phosphatase; GGT: gamma-glutamyl transferase. 
Table 2. List-wise format of each of the 15 unique correlations in the correlation matrix.

\begin{tabular}{cccc}
\hline Row & Column & Correlation & $p$-Value \\
\hline Liver-to-body weight ratio & Bilirubin & 0.37 & 0.0210 \\
\hline Liver-to-body weight ratio & Total GSH & -0.17 & 0.3897 \\
\hline Liver-to-body weight ratio & GSSG/GSH & 0.28 & 0.1465 \\
\hline Liver-to-body weight ratio & Sinusoidal dilation & 0.42 & 0.0065 \\
\hline Liver-to-body weight ratio & Necrosis & 0.56 & 0.0002 \\
\hline Bilirubin & Total GSH & -0.49 & 0.0043 \\
\hline Bilirubin & GSSG/GSH & 0.48 & 0.0054 \\
\hline Bilirubin & Sinusoidal dilation & 0.61 & $<0.0001$ \\
\hline Bilirubin & Necrosis & 0.67 & $<0.0001$ \\
\hline Total GSH & GSSG/GSH & -0.69 & $<0.0001$ \\
\hline Total GSH & Sinusoidal dilation & -0.75 & $<0.0001$ \\
\hline Total GSH & Necrosis & -0.70 & $<0.0001$ \\
\hline GSSG/GSH & Sinusoidal dilation & 0.74 & $<0.0001$ \\
\hline GSSG/GSH & Necrosis & 0.71 & $<0.0001$ \\
\hline Sinusoidal dilation & Necrosis & 0.86 & $<0.0001$ \\
\hline
\end{tabular}

\subsection{Molecular Alterations Associated with CRCE/APAP}

To gain insight into the mechanisms of CBD-induced exacerbation of APAP hepatotoxicity, we first measured expression of a panel of genes involved in the metabolism of CBD and APAP. APAP itself did not cause substantial changes in mRNA levels in any of the investigated genes, except for Ugt1a6 and Ugt2a3 transferases (Figure 2). However, dose-dependent increases in the expression of numerous CYPs and UGTs were observed in the CBD treated mice. Furthermore, the CBD + APAP group had increased expression of Cyp2b10, and a strong interaction effect was observed in the case of Cyp2e1 after 290 mg/kg CBD + APAP, but not after 116 mg/kg CBD + APAP (Figure 3). 

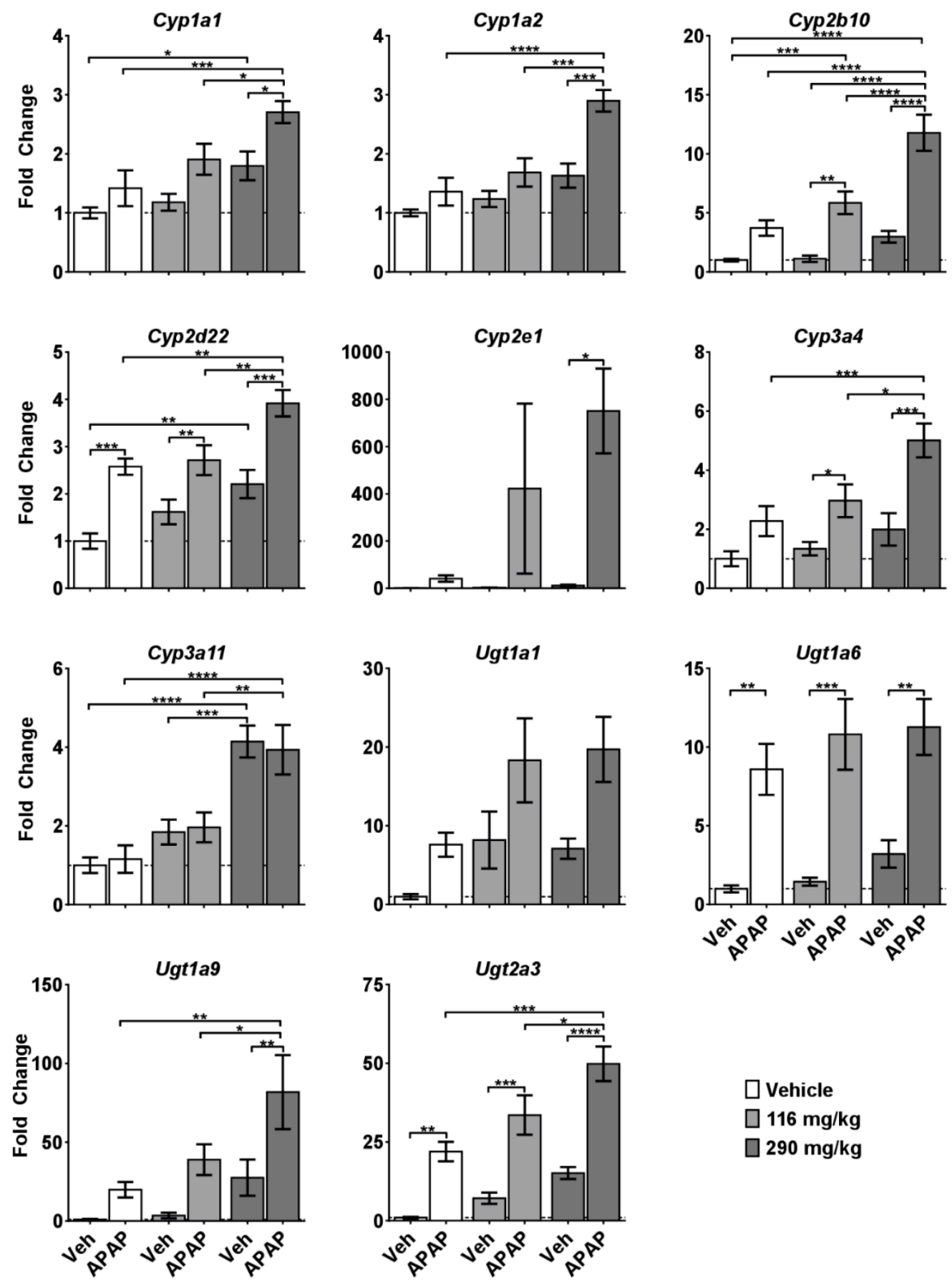

Figure 3. Effects of CRCE/APAP co-administration on intrahepatic expression of cytochrome P450s and UDP-glucuronosyltransferases. Livers were collected $5 \mathrm{~h}$ after APAP administration and gene expression was measured using the quantitative real-time (qRT) PCR. Veh $(n=7)$; Veh + APAP $(n=7)$; $116 \mathrm{mg} / \mathrm{kg}$ CBD $(n=7) ; 116 \mathrm{mg} / \mathrm{kg}$ CBD + APAP $(n=7) ; 290 \mathrm{mg} / \mathrm{kg} \mathrm{CBD}(n=8) ; 290 \mathrm{mg} / \mathrm{kg}$ CBD $+\operatorname{APAP}(n=8)$. Data presented as mean \pm SEM fold changed from vehicle $\left({ }^{*} p<0.05 ;{ }^{* *} p<0.01\right.$; ${ }^{* * *} p<0.001$; and $\left.{ }^{* * * *} p<0.0001\right)$. The following genes were changed significantly with either CBD or APAP, but the two-way ANOVA did not yield any significant comparisons: Cyp2d22 (APAP, $p=0.0016$ ), Ugt1a1 (CBD, $p=0.0186$; APAP, $p=0.0255)$, Ugt1a6 (CBD, $p=0.0222)$, and Ugt1a9 (APAP, $p=0.0026)$.

\subsection{Mechanisms of CRCE/APAP-Induced Liver Injury}

Metabolism of APAP to the reactive metabolite ( $N$-acetyl-p-benzoquinone imine; NAPQI) through the CYP P450s, especially CYP2E1, is well recognized for its role in the initiation of toxicity [18]. 
Because of the robust increase in Cyp $2 e 1 \mathrm{mRNA}$ levels observed in the $290 \mathrm{mg} / \mathrm{kg}$ CBD + APAP group, we hypothesized that CBD increases metabolism and bioactivation of APAP. Therefore, we measured acetaminophen protein adducts levels (APAP-CYS), a generally recognized biomarker of APAP exposure linked to the formation of toxic NAPQI. APAP-CYS were increased in the APAP treated mice. However, no difference in APAP-CYS were observed among the Veh + APAP, compared to the $116 \mathrm{mg} / \mathrm{kg}$ CBD+APAP and $290 \mathrm{mg} / \mathrm{kg}$ CBD+APAP mice (Figure 4A). Furthermore, there was no correlation between the degree of liver injury observed in the mice and the amount of APAP-CYS.
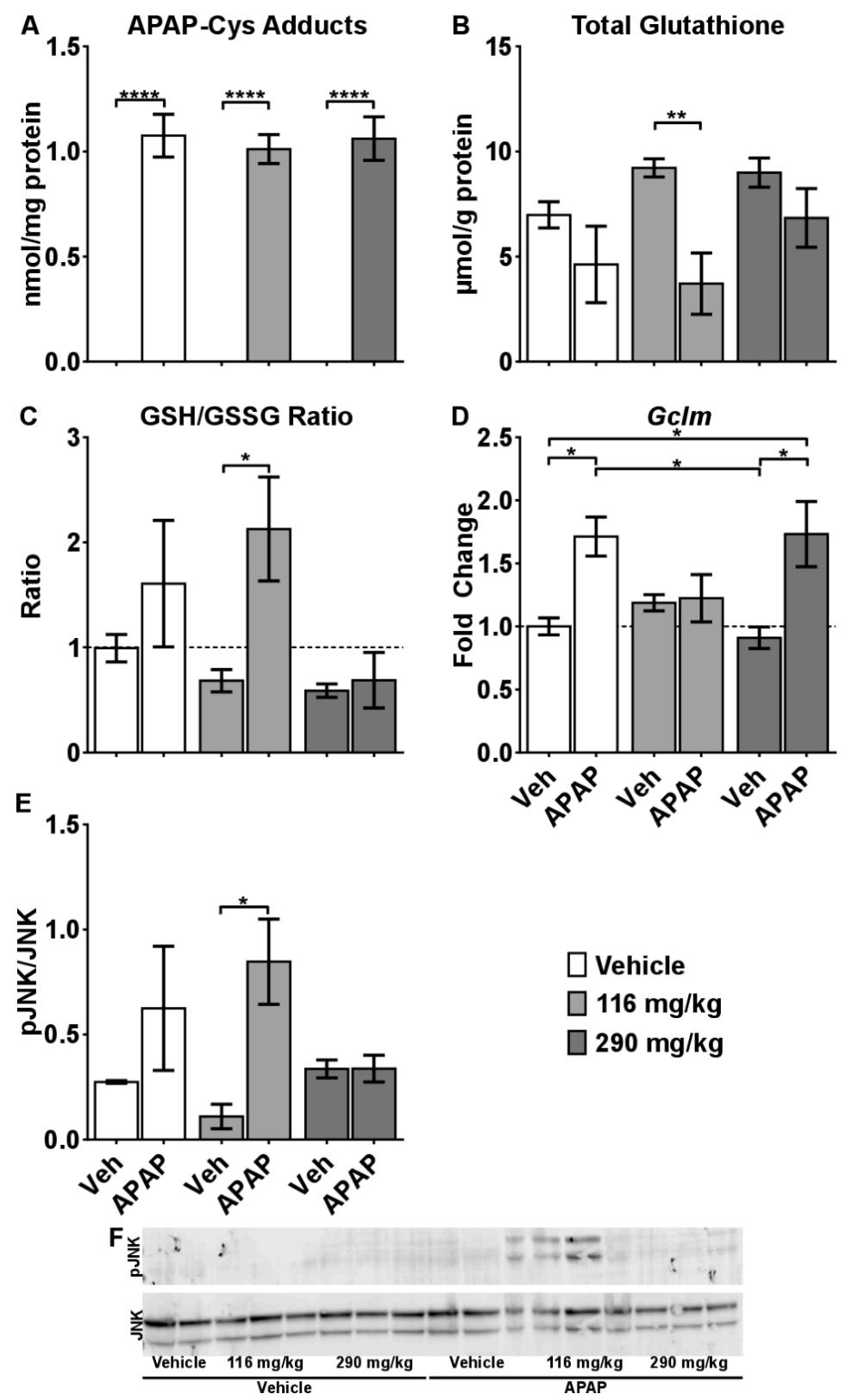

Figure 4. Mechanisms of CRCE/APAP-induced liver injury. (A) APAP-Cys protein adducts; levels of (B) GSH, and (C) GSSG/GSH; (D) mRNA levels of Gclm as measured by quantitative real-time (qRT) PCR; E) protein levels of Jnk and pJNK as measured by Western blot; and F) representative blot. Veh $(n=7)$; Veh + APAP $(n=7) ; 116 \mathrm{mg} / \mathrm{kg} \mathrm{CBD}(n=7) ; 116 \mathrm{mg} / \mathrm{kg}$ CBD + APAP $(n=7) ; 290 \mathrm{mg} / \mathrm{kg}$ CBD $(n=8) ;$ $290 \mathrm{mg} / \mathrm{kg}$ CBD + APAP $(n=8)$. Data presented as mean \pm SEM fold changed from vehicle $(* p<0.05$; ** $p<0.01$; and $\left.{ }^{* * * *} p<0.0001\right)$. GSSG levels were significantly affected by APAP $(p=0.0151)$, but there are no significant comparisons. 
APAP depletes hepatic glutathione very early in the time course of APAP toxicity (e.g., $1 \mathrm{~h}$ ) in the mouse, and re-synthesis occurs after $4 \mathrm{~h}$ [19]. Glutathione depletion causes oxidative stress and also contributes to SOS [20]. At $5 \mathrm{~h}$, hepatic GSH was not statistically different in the Veh + APAP mice (although trend towards reduction was observed), but was significantly reduced in the mice receiving $116 \mathrm{mg} / \mathrm{kg}$ CBD + APAP (Figure 4B). In mice administered $290 \mathrm{mg} / \mathrm{kg}$ CBD + APAP, an unexpected and rapid re-synthesis of glutathione was observed, in which total glutathione approximated that observed in control mice (Figure 4B). Interestingly, the GSSG/GSH ratio, an indicator of liver redox status, was spiked in $116 \mathrm{mg} / \mathrm{kg}$ CBD+APAP, but not in the other groups (Figure 4C). Furthermore, the highest GSSG/GSH values-indicative of an overwhelming state of oxidative liver stress-were observed in mice characterized by the highest degree of histopathological, physiological, and biochemical end-points of liver injury (Table 2).

To further confirm these findings, we performed mRNA analysis of Gclm, one of the rate-limiting enzymes for glutathione re-synthesis, and determined protein levels of phosphorylated JNK, which is known to be activated by oxidative stress. Consistent with histopathological, physiological and clinical biochemistry data, significant increases in Gclm expression were observed in the vehicle + APAP and $290 \mathrm{mg} / \mathrm{kg}$ CBD + APAP groups, suggesting rapid re-synthesis of glutathione (Figure 4D). However, expression of Gclm was not induced in the $116 \mathrm{mg} / \mathrm{kg}$ CBD + APAP mice, indicating that the normal response to enhance re-synthesis of glutathione was impaired. Lastly, we observed increased JNK phosphorylation in $116 \mathrm{mg} / \mathrm{kg}$ CBD+APAP mice (Figure 3E,F). Taken together, these data are consistent with the hypothesis that $116 \mathrm{mg} / \mathrm{kg}$ CBD enhanced overall toxicity by increasing hepatic JNK activation and impairing glutathione synthesis.

\section{Conclusions}

Here, for the first time, the in vivo potential for a $\mathrm{CBD} /$ drug interaction resulting in liver injury has been demonstrated. Treatment of mice with clinically relevant CBD doses in CRCE for three consecutive days, followed by a challenge with APAP, resulted in the development of an SOS-like pattern of liver injury and mortality, neither of which were observed in the Veh + APAP group. Mechanistically, the observed effect was associated with an overwhelming oxidative catastrophe triggered by massive oxidative stress, rapid depletion of liver glutathione, impaired glutathione re-synthesis, and greater JNK activation. Of particular concern, this effect was observed after administration of the lower, $116 \mathrm{mg} / \mathrm{kg}$, CBD dose in CRCE (i.e., MED = $10 \mathrm{mg} / \mathrm{kg}$ ). Further studies are clearly needed to investigate this paradoxical effect and its mechanisms.

Congruent with the results of our study, emerging evidence suggests that CBD creates a significant drug interaction that could lead to serious adverse health effects, including liver injury. For instance, in a recent clinical trial, combining CBD with valproic acid led to a more robust elevation in liver enzymes, such that liver transaminases were $\geq 3$ times the upper limit of normal in $17 \%$ of patients [21]. Our data corroborate recent clinical observations regarding CBD hepatotoxicity and caution against its casual, non-medically supervised usage with potentially hepatotoxic medications.

\section{Materials and Methods}

\subsection{CBD Extract Characterization, Dosing Solution and Dose Calculations}

Cannabidiol-rich cannabis extract (CRCE) was prepared at the University of Mississippi's National Center for Natural Product Research by extraction of CBD rich cannabis plant material (5.61\% of CBD and $0.2 \% \mathrm{THC}$ ) using hexane as the extraction solvent. The extract was then evaporated to dryness, followed by raising the temperature to $80^{\circ} \mathrm{C}$ to affect complete decarboxylation of the extract.

Phytochemical analysis of CRCE showed the following: cannabidiol content-57.9\%; other cannabinoids: cannabichromene-2.03\%, $\Delta^{9}$-tetrahydrocannabinol-1.69\%, cannabigerol-1.07\%, $\Delta^{8}$-tetrahydrocannabinol- $<0.01 \%$; tetrahydrocannabivarin- $<0.01 \%$. The residual solvent was $<0.5 \%$; 
loss on drying- $0.32 \%$; heavy metals: lead, mercury, cadmium, and arsenic-not detected; aflatoxins: $\mathrm{AFB}_{1}, \mathrm{AFB}_{2}, \mathrm{AGF}_{1}, \mathrm{AFG}_{2}$-not detected.

CRCE dose was calculated based on CBD content in the characterized extract to deliver the required dose of CBD. The extract was diluted in sesame oil to prepare the gavage solution. Allometric scaling for CBD mouse equivalent doses (MED) was determined per the recommendation of Wojcikowski and Gobe which, in turn, is based upon the FDA Industry Guidance for Estimating the Maximum Safe Starting Dose in Initial Clinical Trials for Therapeutics in Adult Volunteers [22]. The scaling factor of 11.6, commonly used for mice weighing between $36-50 \mathrm{~g}$, was used to calculate the MED for CBD, using the lowest recommended human maintenance dose of CBD $\left(10 \mathrm{mg} / \mathrm{kg}\right.$ EPIDIOLEX $\left.{ }^{\circledR}\right)$. Thus, $1 \mathrm{X}$ and 2.5X MED doses consisted of $5.104 \mathrm{mg}$ total CBD $(116 \mathrm{mg} / \mathrm{kg})$ and $18.45 \mathrm{mg}$ total CBD $(290 \mathrm{mg} / \mathrm{kg}$ respectively, delivered in $300 \mu \mathrm{L}$ of gavage CRCE solution in sesame oil. Similar doses were used in our previous 2-week repeated dosing study on CBD and were not associated with hepatotoxicity [7]. Control mice received $300 \mu \mathrm{L}$ of sesame oil.

\subsection{Animals}

Nulliparous female CD-1 mice were purchased from Charles River (Wilmington, MA, USA) and aged at the University of Arkansas for Medical Sciences (UAMS) Division of Laboratory Animal Medicine (DLAM) facility. We used outbred mice in order to mimic the genetic heterogeneity of humans. At 9 months of age, mice were randomly assigned to the following groups: control $(n=7), 116 \mathrm{mg} / \mathrm{kg}$ $\mathrm{CBD}(n=7), 290 \mathrm{mg} / \mathrm{kg} \mathrm{CBD}(n=8), \operatorname{APAP}(400 \mathrm{mg} / \mathrm{kg} ; n=7), 116 \mathrm{mg} / \mathrm{kg} \mathrm{CBD}+\operatorname{APAP}(n=8)$, and $290 \mathrm{mg} / \mathrm{kg}$ CBD + APAP ( $\mathrm{n}=8$ ). APAP was purchased from Sigma (St. Louis, MO, USA; >98\% purity). Mice were gavaged with CRCE for three consecutive days at 0800, followed by i.p. injection of APAP $(400 \mathrm{mg} / \mathrm{kg}$ ) dissolved in warm PBS on day 4 . With this experimental setup, we sought to mimic conventional usage of CBD followed by ingestion of a high dose of APAP, a likely scenario given the popularity of both compounds. Animals were euthanized $5 \mathrm{~h}$ after APAP administration. To avoid any potential fasting-exacerbated toxicity, food and water were provided ad libitum. All procedures were approved by the UAMS Institutional Animal Care and Use Committee (protocol number: AUP \#3701).

\subsection{Blood Sampling and Clinical Biochemistry}

Blood was collected from the retro-orbital plexus with a heparinized micro-hematocrit capillary tube (Fisher Scientific, Pittsburg, PA, USA) and placed into a $1.1 \mathrm{~mL}$ Z-gel microtube (Sarstedt, Newton, NC, USA). Tubes were kept on ice prior to centrifugation at 10,000 rpm for $20 \mathrm{~min}$; serum samples were delivered to the Veterinary Diagnostic Laboratory at the Arkansas Livestock and Poultry Commission (Little Rock, AR, USA) for further analysis.

\subsection{Histopathological Assessment}

Liver sections were fixed in $4 \%$ formalin and processed at the UAMS Pathology Core Facility. Two independent, blinded pathologists evaluated the hematoxylin eosin sections at 20×, 40×, 100×, $200 \times$, and 400x magnification, as described in Supplementary Materials and Methods.

\subsection{Analysis of mRNA Levels of Major Cytochromes and Transporter Genes}

Total RNA was extracted from flash frozen liver tissue using the RNeasy Mini Kit (Qiagen, Germantown, MD, USA). Following purification, $1000 \mathrm{ng}$ were reverse transcribed with the High Capacity cDNA Reverse Transcription Kit (ThermoFisher, Waltham, MA, USA). Primers were added at a final concentration of $5 \mu \mathrm{M}$ (Supplementary Table S1). Gene expression values were calculated as fold change from control according to the ${ }_{\Delta \Delta} \mathrm{CT}$ method. 


\subsection{Analysis of the APAP Protein Adducts in the Liver Tissue}

APAP-protein adducts were measured as previously described, with modifications $[23,24]$. Details are provided in Supplementary Materials and Methods.

\subsection{Glutathione Analysis}

Hepatic glutathione was measured using a modified Tietze assay [25] as described in Supplementary Materials and Methods.

\subsection{Western Blot}

Protein levels for JNK and pJNK were measured by western blot, as previously described [26].

\subsection{Statistical Analysis}

Data were analyzed with either Graphpad Prism 6 software (Graphpad Software, San Diego, CA, USA) or R (The R Foundation). The primary contrasts of interest were Vehicle + APAP at CBD doses of 0,116 , and $290 \mathrm{mg} / \mathrm{kg}$ for each of the measured study parameters. A $2 \times 3$ factorial arrangement of treatments analysis of variance model was fit to each response variable. Next, the above three contrasts were computed using a Bonferroni correction to assure a $95 \%$ family-wise confidence level. Interaction effects were evaluated using a two-way ANOVA. Bonferrroni adjusted $p$-values were also computed. Histology scores were analyzed with a Mann-Whitney test comparing vehicle versus APAP at each CBD dose. $p$-values were adjusted with a Bonferroni correction ( 3 comparisons for $\alpha \leq 0.0167$ ). Response variables were also analyzed for correlation using Spearman's Rank Correlation due to non-continuous data in the histological analyses.

Supplementary Materials: The following are available online, Table S1: Forward and reverse primer sequences for cytochrome P450s and UDP-gluconosyltrasferases, Figure S1: Changes in body weight and organ-to-body weight ratios after $\mathrm{CBD} \pm \mathrm{APAP}$, Figure $\mathrm{S} 2$ : Clinical chemistry parameters in the serum of experimental mice.

Author Contributions: Conceptualization, L.A.W., M.A.E., B.J.G. and I.K.; Data curation, L.E.E. and I.K.; Formal analysis, L.E.E., M.R.M., E.U.Y., C.M.Q., C.M.S., S.K.M., M.C., J.H.V., S.S.M., D.K.W., K.R.K., M.A.E., L.P.J., B.J.G. and I.K.; Funding acquisition, M.R.M. and I.K.; Investigation, L.E.E., C.M.S., M.R.M., M.E.E., B.J.G. and I.K.; Methodology, M.A.E.; Resources, B.J.G.; Writing - original draft, M.R.M., M.A.E., L.P.J., B.J.G. and I.K.

Funding: This work was supported by the National Institute of General Medical Sciences [grant \# P20 GM109005 to IK], the American Association for the Study of Liver Diseases (AASLD) Foundation [Pinnacle Research Award to MRM], and the Arkansas Biosciences Institute.

Acknowledgments: The authors are thankful to Robin Mulkey and Bridgette Engi for excellent animal care at the UAMS Animal Facility.

Conflicts of Interest: Quick serves as a scientific consultant for Allergan. James is a co-owner of Acetaminophen Toxicity Diagnostics, LLC. No conflicts of interest are declared by the other authors.

\section{References}

1. Devinsky, O.; Cross, J.H.; Wright, S. Trial of Cannabidiol for Drug-Resistant Seizures in the Dravet Syndrome. N. Engl. J. Med. 2017, 377, 699-700. [CrossRef] [PubMed]

2. Thiele, E.A.; Marsh, E.D.; French, J.A.; Mazurkiewicz-Beldzinska, M.; Benbadis, S.R.; Joshi, C.; Lyons, P.D.; Taylor, A.; Roberts, C.; Sommerville, K.; et al. Cannabidiol in patients with seizures associated with Lennox-Gastaut syndrome (GWPCARE4): A randomised, double-blind, placebo-controlled phase 3 trial. Lancet 2018, 391, 1085-1096. [CrossRef]

3. Bonini, S.A.; Premoli, M.; Tambaro, S.; Kumar, A.; Maccarinelli, G.; Memo, M.; Mastinu, A. Cannabis sativa: A comprehensive ethnopharmacological review of a medicinal plant with a long history. J. Ethnopharmacol. 2018, 227, 300-315. [CrossRef] [PubMed]

4. Premoli, M.; Aria, F.; Bonini, S.A.; Maccarinelli, G.; Gianoncelli, A.; Pina, S.D.; Tambaro, S.; Memo, M.; Mastinu, A. Cannabidiol: Recent advances and new insights for neuropsychiatric disorders treatment. Life Sci. 2019, 224, 120-127. [CrossRef] [PubMed] 
5. Rosenkrantz, H.; Fleischman, R.W.; Grant, R.J. Toxicity of short-term administration of cannabinoids to rhesus monkeys. Toxicol. Appl. Pharmacol. 1981, 58, 118-131. [CrossRef]

6. Gamble, L.J.; Boesch, J.M.; Frye, C.W.; Schwark, W.S.; Mann, S.; Wolfe, L.; Brown, H.; Berthelsen, E.S.; Wakshlag, J.J. Pharmacokinetics, Safety, and Clinical Efficacy of Cannabidiol Treatment in Osteoarthritic Dogs. Front. Vet. Sci. 2018, 5, 165. [CrossRef] [PubMed]

7. Ewing, L.E.; Skinner, C.M.; Quick, C.M.; Kennon-McGill, S.; McGill, M.R.; Walker, L.A.; ElSohly, M.A.; Gurley, B.J.; Koturbash, I. Hepatotoxicity of a Cannabidiol-Rich Cannabis Extract in the Mouse Model. Molecules 2019, 24, 1694. [CrossRef] [PubMed]

8. Devinsky, O.; Patel, A.D.; Cross, J.H.; Villanueva, V.; Wirrell, E.C.; Privitera, M.; Greenwood, S.M.; Roberts, C.; Checketts, D.; VanLandingham, K.E.; et al. Effect of Cannabidiol on Drop Seizures in the Lennox-Gastaut Syndrome. N. Engl. J. Med. 2018, 378, 1888-1897. [CrossRef] [PubMed]

9. Mazur, A.; Lichti, C.F.; Prather, P.L.; Zielinska, A.K.; Bratton, S.M.; Gallus-Zawada, A.; Finel, M.; Miller, G.P.; Radominska-Pandya, A.; Moran, J.H. Characterization of human hepatic and extrahepatic UDP-glucuronosyltransferase enzymes involved in the metabolism of classic cannabinoids. Drug Metab. Dispos. 2009, 37, 1496-1504. [CrossRef] [PubMed]

10. Stout, S.M.; Cimino, N.M. Exogenous cannabinoids as substrates, inhibitors, and inducers of human drug metabolizing enzymes: A systematic review. Drug Metab. Rev. 2014, 46, 86-95. [CrossRef]

11. Zendulka, O.; Dovrtelova, G.; Noskova, K.; Turjap, M.; Sulcova, A.; Hanus, L.; Jurica, J. Cannabinoids and Cytochrome P450 Interactions. Curr. Drug Metab. 2016, 17, 206-226. [CrossRef] [PubMed]

12. Suh, J.H.; Shenvi, S.V.; Dixon, B.M.; Liu, H.; Jaiswal, A.K.; Liu, R.M.; Hagen, T.M. Decline in transcriptional activity of Nrf2 causes age-related loss of glutathione synthesis, which is reversible with lipoic acid. Proc. Natl. Acad. Sci. USA 2004, 101, 3381-3386. [CrossRef] [PubMed]

13. Klotz, U. Pharmacokinetics and drug metabolism in the elderly. Drug Metab. Rev. 2009, 41, 67-76. [CrossRef] [PubMed]

14. Kaufman, D.W.; Kelly, J.P.; Rosenberg, L.; Anderson, T.E.; Mitchell, A.A. Recent patterns of medication use in the ambulatory adult population of the United States: The Slone survey. JAMA 2002, 287, 337-344. [CrossRef] [PubMed]

15. Miousse, I.R.; Skinner, C.M.; Lin, H.; Ewing, L.E.; Kosanke, S.D.; Williams, D.K.; Avula, B.; Khan, I.A.; ElSohly, M.A.; Gurley, B.J.; et al. Safety assessment of the dietary supplement OxyELITE Pro (New Formula) in inbred and outbred mouse strains. Food Chem. Toxicol. 2017, 109, 194-209. [CrossRef] [PubMed]

16. Skinner, C.M.; Miousse, I.R.; Ewing, L.E.; Sridharan, V.; Cao, M.; Lin, H.; Williams, D.K.; Avula, B.; Haider, S.; Chittiboyina, A.G.; et al. Impact of obesity on the toxicity of a multi-ingredient dietary supplement, OxyELITE Pro (New Formula), using the novel NZO/HILtJ obese mouse model: Physiological and mechanistic assessments. Food Chem. Toxicol. 2018, 122, 21-32. [CrossRef] [PubMed]

17. Zhu, J.; Seo, J.E.; Wang, S.; Ashby, K.; Ballard, R.; Yu, D.; Ning, B.; Agarwal, R.; Borlak, J.; Tong, W.; et al. The Development of a Database for Herbal and Dietary Supplement Induced Liver Toxicity. Int. J. Mol. Sci. 2018, 19, 2955. [CrossRef] [PubMed]

18. Mitchell, J.R.; Jollow, D.J.; Potter, W.Z.; Davis, D.C.; Gillette, J.R.; Brodie, B.B. Acetaminophen-induced hepatic necrosis. I. Role of drug metabolism. J. Pharmacol. Exp. Ther. 1973, 187, 185-194. [PubMed]

19. James, L.P.; McCullough, S.S.; Lamps, L.W.; Hinson, J.A. Effect of $\mathrm{N}$-acetylcysteine on acetaminophen toxicity in mice: Relationship to reactive nitrogen and cytokine formation. Toxicol. Sci. 2003, 75, 458-467. [CrossRef]

20. Fan, C.Q.; Crawford, J.M. Sinusoidal obstruction syndrome (hepatic veno-occlusive disease). J. Clin. Exp. Hepatol. 2014, 4, 332-346. [CrossRef]

21. Devinsky, O.; Nabbout, R.; Miller, I.; Laux, L.; Zolnowska, M.; Wright, S.; Roberts, C. Long-term cannabidiol treatment in patients with Dravet syndrome: An open-label extension trial. Epilepsia 2019, 60, 294-302. [CrossRef] [PubMed]

22. Wojcikowski, K.; Gobe, G. Animal studies on medicinal herbs: Predictability, dose conversion and potential value. Phytother. Res. 2014, 28, 22-27. [CrossRef] [PubMed]

23. Muldrew, K.L.; James, L.P.; Coop, L.; McCullough, S.S.; Hendrickson, H.P.; Hinson, J.A.; Mayeux, P.R. Determination of acetaminophen-protein adducts in mouse liver and serum and human serum after hepatotoxic doses of acetaminophen using high-performance liquid chromatography with electrochemical detection. Drug Metab. Dispos. 2002, 30, 446-451. [CrossRef] [PubMed] 
24. McGill, M.R.; Lebofsky, M.; Norris, H.R.; Slawson, M.H.; Bajt, M.L.; Xie, Y.; Williams, C.D.; Wilkins, D.G.; Rollins, D.E.; Jaeschke, H. Plasma and liver acetaminophen-protein adduct levels in mice after acetaminophen treatment: Dose-response, mechanisms, and clinical implications. Toxicol. Appl. Pharmacol. 2013, 269, 240-249. [CrossRef] [PubMed]

25. McGill, M.R.; Jaeschke, H. A direct comparison of methods used to measure oxidized glutathione in biological samples: 2-vinylpyridine and N-ethylmaleimide. Toxicol. Mech. Methods 2015, 25, 589-595. [CrossRef] [PubMed]

26. McGill, M.R.; Du, K.; Xie, Y.; Bajt, M.L.; Ding, W.X.; Jaeschke, H. The role of the c-Jun N-terminal kinases 1/2 and receptor-interacting protein kinase 3 in furosemide-induced liver injury. Xenobiotica 2015, 45, 442-449. [CrossRef]

Sample Availability: Samples are not available.

(C) 2019 by the authors. Licensee MDPI, Basel, Switzerland. This article is an open access article distributed under the terms and conditions of the Creative Commons Attribution (CC BY) license (http://creativecommons.org/licenses/by/4.0/). 